\title{
Employing Case Studies To Develop Professional Skills In South African Accountancy Students: A Comparative Follow-Up Study
}

Francois Steyn, University of the Western Cape, South Africa Carol Cairney, University of the Western Cape, South Africa Nico van der Merwe, North-West University, South Africa

\begin{abstract}
Some of the main challenges faced in accounting education are developing professional skills and encouraging deep learning in students. The literature offers numerous accounts of the case study method as a successful tool for developing professional skills and linking theory with practice. This paper reports on a follow-up study which aimed to contribute to the field in three ways: 1) in corroborating the findings of a prior study on case studies as a tool to develop professional skills, 2) by investigating whether changes in the way the case study was administered had an effect on students' perceived development, and 3) by gaining some insight into the actual learning that took place by analyzing the assessment outcomes. The findings show that the changes in the way the assignment was administered had no significant effect on the perceptions of students, but that team selection and the provision of homework assistance should be carefully considered. The assessment results support students' generally positive perceptions on their development of certain professional skills, although deep learning seems to remain a challenge. The paper highlights the importance of research in the field of teaching and learning in accounting education in order to better equip accounting students for the "real world".
\end{abstract}

Keywords: Accounting Education; Professional Skills; Case Study; Teaching and Learning; Assessment; Deep Learning; Team Selection; Homework Assistance

\section{INTRODUCTION}

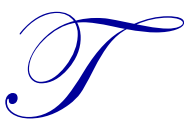

his paper is a continuation of a previous study (Van der Merwe, 2013) reporting on the perceptions of a group of South African (SA) accounting students on the introduction of an integrated case study assignment as part of their third-year degree course. The assignment was included in the curriculum in order to address the apparent failure of universities to sufficiently equip their students with the soft skills required in the workplace (Barac, 2009; De Lange, Jackling \& Gut, 2006; Kavanagh \& Drennan, 2008). The South African Institute of Chartered Accountants' (SAICA) Competency Framework (CF) includes these pervasive skills as an important requirement for prospective chartered accountants (CAs) (SAICA, 2014).

Van der Merwe (2013) cites numerous papers where case studies (e.g., Ashbaugh \& Johnstone, 2000; Ahmad, 2011; Ballantine \& McCourt Larres, 2004; Hassall \& Milne, 2004; Healy \& McCutcheon, 2010; Weil, Oyelere \& Rainsbury, 2004; Wynn-Williams, Whiting \& Adler, 2008) and business simulations, including role play (e.g., Avramenko, 2012; Fortin \& Legault, 2010; Fouché \& Visser, 2008; Hassall \& Milne, 2004; Steenkamp \& Rudman, 2007; Towler, Lean \& Moizer, 2009; Xu \& Yang, 2010) have been used successfully in promoting the development of soft skills in accounting, but highlights the lack of integration of all the core subject areas (auditing, financial accounting, corporate governance, managerial accounting and taxation) in a review of four years of accounting education literature by Apostolou, Hassell, Rebele and Watson (2010). Integration is an important feature of the assessment of professional competence (APC) that is written before qualifying as a South African CA, and the Higher Education Qualifications 
Framework (HEQF) of South Africa requires at least one integrated assessment for each degree qualification (Council on Higher Education, 2004).

For this study the original case study assignment (Van der Merwe, 2013) was borrowed with permission from the author and administered at a different South African university with a larger population. The students came from more or less the same background, being from previously disadvantaged groups, and were also in their third year of their degree in accounting. Some changes were made in the way that the assignment was administered, e.g., participation was compulsory and formed part of the students' continuous assessment mark (CAM); they were allocated heterogeneously to a team by the instructor; no homework assistance was given during the course of the assignment; and they attended a short course on skills development and case analysis before the assignment started. At the completion of the assignment the participants were asked to complete a survey questionnaire, which Van der Merwe (2013) adapted from a previous study, on students' experiences of a simulation assignment (Fouché \& Visser, 2008).

The main objective of this study was to compare accounting students' perceived development of professional skills by participating in an integrated case study at two different institutions. To address the main objective, two research questions were formulated:

Research question 1: "Do accounting students perceived development of their professional skills by participating in an integrated case study assignment differ when repeated at a different institution?"

Research question 2: "Do accounting students perceived development of their professional skills differ when changes are made in the way that the case study is administered?"

A secondary aim was to investigate whether case study assignments are effective for deeper levels of learning. To address this secondary aim, a third research question was formulated:

Research question 3: "Are case study assignments effective in addressing the lack of professional skills and attributes in accounting curricula by encouraging deeper levels of learning?"

To answer the first two research questions, the responses of the follow-up study were compared to those of the original study by analyzing the results descriptively and statistically. The third research question was answered by grouping the assessment criteria into "soft skills" and "professional attributes" to test whether the assignment was equally effective in addressing skills development and deeper learning. This study aimed to contribute to the accounting education literature by corroborating or contradicting the results of the original study (Van der Merwe, 2013) and by offering some insight into the effectiveness of integrated case studies in developing soft skills and professional attributes that are such important requirements in becoming a CA.

The following section provides a review of the relevant literature supporting the main objectives of the study, followed by an explanation of the research methodology. Next the findings of the study are presented, before concluding with a reflection on the study and suggestions of areas for further research.

\section{LITERATURE REVIEW}

To support the relevance of this study, this section offers a review of the recent literature on the skills required by professional accountants and the importance thereof. Attention will also be paid to ways in which students acquire knowledge as motivation for developing and including case study assignments in accounting curricula.

The original study that inspired this follow-up paper was conducted to address the lack of focus on the development of professional skills and attributes in accounting curricula at universities. During a review of the literature, Van der Merwe (2013) identified numerous skills that are central to accounting practice. These skills can be broadly categorized into the following ten categories: Soft skills; communication; technology; time management; teamwork; real-world experience; financial literacy; critical thinking and problem solving; professional judgement; and ethics. The importance of these skills in accounting curricula is supported by the more recent literature. 
At least two out of the three studies investigating the gap between the expectations of employers and graduates highlight the need to develop the following skills: communication; technology; teamwork; real-world experience; critical thinking and problem solving; and professional judgement (Abayadeera \& Watty, 2014; Tanaka \& Sithole, 2015; Yu, Churyk \& Chang, 2013). Yu et al. (2013) analyzed the gap between interns' perceived skillsets and employers' satisfaction with interns' skills, and further highlight financial literacy and ethics as important areas for development. In a study comparing the expectations of employers and graduate achievement, soft skills were identified as requiring attention (Abayadeera \& Watty, 2014).

Numerous studies investigating the skills expectations of potential employers identify communication; teamwork; critical thinking and problem solving as important (Finch, Hamilton, Baldwin \& Zehner, 2013; Howieson, Hancock, Segal, Kavanagh, Tempone \& Kent, 2014; Robles, 2012), while mention of critical thinking in job postings have doubled since 2009 (Korn, 2014). Soft skills and professional judgement (Finch et al., 2013; Robles, 2012), as well as technology and financial literacy (Finch et al., 2013; Howieson et al., 2014), were also reported to be high in demand.

Low, Samkin and Liu (2013) found that some of the challenges reportedly faced by graduates in the workplace are soft skills, communication, time management, teamwork, and real-world experience, while a survey of heads of accounting departments found that almost all of the categories of skills identified by Van der Merwe (2013) are reported to be integrated into accounting curricula at the participating institutions. Martinov-Bennie and Mladenovic (2015) assessed the impact of training on students' sensitivity and judgement to ethical issues. Table 1 summarizes how the more recent literature corroborates earlier research reviewed by Van der Merwe (2013).

Table 1. Professional skills and attributes requiring attention in accounting curricula

\begin{tabular}{|c|c|c|c|c|c|c|c|c|c|c|c|}
\hline Study & 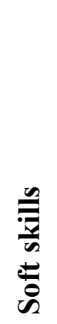 & 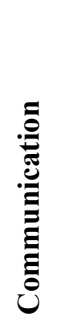 & 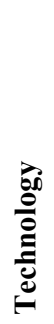 & 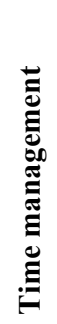 & 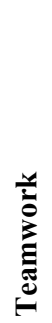 & 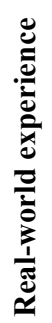 & 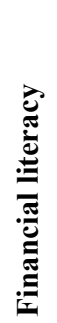 & 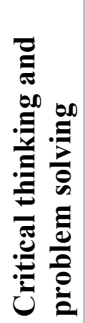 & 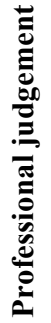 & 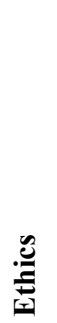 & Aim of study \\
\hline Abayadeera and Watty (2014) & $\mathrm{x}$ & $\mathrm{x}$ & & $\mathrm{x}$ & $\mathrm{x}$ & $\mathrm{x}$ & & & $\mathrm{x}$ & & Expectation gap \\
\hline Tanaka and Sithole (2015) & & $\mathrm{x}$ & $\mathrm{x}$ & & & & & $\mathrm{x}$ & $\mathrm{x}$ & & Expectation gap \\
\hline Yu et al. (2013) & & $\mathrm{x}$ & $\mathrm{x}$ & $\mathrm{x}$ & $\mathrm{x}$ & $\mathrm{x}$ & $\mathrm{x}$ & $\mathrm{x}$ & & $\mathrm{x}$ & Expectation gap \\
\hline Finch et al. (2013) & $\mathrm{x}$ & $\mathrm{x}$ & $\mathrm{x}$ & & $\mathrm{x}$ & $\mathrm{x}$ & $\mathrm{x}$ & $\mathrm{x}$ & $\mathrm{x}$ & & $\begin{array}{l}\text { Employers' } \\
\text { expectations }\end{array}$ \\
\hline Howieson et al. (2014) & & $\mathrm{x}$ & $\mathrm{x}$ & $\mathrm{x}$ & $\mathrm{x}$ & & $\mathrm{x}$ & $\mathrm{x}$ & & & $\begin{array}{l}\text { Employers' } \\
\text { expectations }\end{array}$ \\
\hline Korn 2014 & & & & & & & & $\mathrm{x}$ & & & $\begin{array}{l}\text { Employers' } \\
\text { expectations }\end{array}$ \\
\hline Robles (2012) & $\mathrm{x}$ & $\mathrm{x}$ & & & $\mathrm{x}$ & & & $\mathrm{x}$ & $\mathrm{x}$ & $\mathrm{x}$ & $\begin{array}{l}\text { Employers' } \\
\text { expectations }\end{array}$ \\
\hline Low et al. (2013) & $\mathrm{x}$ & $\mathrm{x}$ & & $\mathrm{x}$ & $\mathrm{x}$ & $\mathrm{x}$ & & & & & $\begin{array}{l}\text { Graduates' } \\
\text { challenges }\end{array}$ \\
\hline Barac and Du Plessis (2014) & & $\mathrm{x}$ & $\mathrm{x}$ & $\mathrm{x}$ & $\mathrm{x}$ & & & $\mathrm{x}$ & $\mathrm{x}$ & $\mathrm{x}$ & $\begin{array}{l}\text { Integration into } \\
\text { curricula }\end{array}$ \\
\hline $\begin{array}{l}\text { Martinov-Bennie and } \\
\text { Mladenovic (2015) }\end{array}$ & & & & & & & & & $\mathrm{x}$ & $\mathrm{x}$ & $\begin{array}{l}\text { Integration into } \\
\text { curricula }\end{array}$ \\
\hline
\end{tabular}

The professional skills and attributes summarized in Table 1 largely correspond to the "professional qualities and skills that all CAs are expected to bring to all tasks" (SAICA, 2014:24). SAICA identifies three categories of pervasive skills: ethical behaviour and professionalism; personal attributes; and professional skills. In the original study Van der 
Merwe (2013) reported that students responded mostly positively to the perceived development of professional skills through participating in the assignment. One area that the original study did not aim to address was the actual learning that took place.

\section{Ways of Knowing: Surface Learning Versus Applied Professional Judgement}

The SAICA CF highlights the importance of CAs' acquiring the fundamental competencies which foster life-long learning and comprehensively address the attitude towards life-long learning and related competencies (SAICA, 2014). Similarly, the International Federation of Accountants' (IFAC) International Education Standards (IES) for Professional Accountants affirm life-long learning as essential in maintaining professional competence. It also regards "a questioning spirit and a life-long desire to learn" the enabling factors for a professional accountant to engage in life-long learning (IFAC, 2003a:38). These standards state that surface approaches to learning are not in the interest of the professional accountant or the profession, as knowledge may become outdated, supporting the educational theory of perennialism (Koenecke, 2012; Link, 2008). Therefore, more important than the personal knowledge base upon entering the profession, are the intellectual skills of understanding, application, analysis and evaluation (IFAC, 2003b).

According to Cairney (2010:9), South African accounting academics perceive students at both undergraduate and postgraduate level to have a large focus on assessment, being interested only in "what they need to know". Consequently, students' study methods are characterised by rote learning, memorisation, pattern recognition and cue seeking in order to identify "what the examiner wants", linking with the theory of behaviourism (Duit \& Treagust, 1998; Schunk, 2011), instead of building their own understanding of the subject areas by applying critical thinking and reflection. These concerns are also raised by markers and umpires in the comments on students' performance in the board examinations (SAICA, 2003-2014). Students are seemingly not applying their knowledge and not thinking through problems in a contextual way as required by both accounting academics and the profession (Cairney, 2010).

In a study comparing the investigation of the ways of knowing between the four main subject areas in an accounting course, an ethics course and life in general, Cairney (2010:44) found that "some element(s) of the academic environment (which includes the subject matter studied) is discouraging students to adopt a more contextual view of the discipline". This is supported by Biggs (1996) who found that a formal academic environment, where marked summative assessments are emphasised, encourages strategic approaches to learning (e.g., cue consciousness and being driven by the demands of assessment) which distract and dissuade students from taking a deep approach to learning. Accounting students are not linking the relatively sterile classroom activities with the "chaotic real world" (Riley, Cadotte, Bonney \& MacGuire, 2013:820).

Accounting education calls for a learning environment that develops deeper approaches to learning that is required in order for knowledge to be applied in different contexts, an ability not supported by rote learning (Byrne \& Flood, 2003; Hall, Ramsay \& Raven, 2004). The ability to apply knowledge and compare and contrast evidence across different contexts is necessary for the development of the highest level of reflective thought (Baxter-Magolda, 2001) and critical reflection (Mezirow, 1998). It is necessary for professionals to be reflective in order to be able to respond appropriately to the changing environment in which they operate, deal with ill-structured problems that involve uncertainty, not reach hasty conclusions and exercise professional judgement (Leung \& Kember, 2003; Lucas \& Tan, 2006a; SAICA, 2014).

Educators are urged to deliberately address the contextualization of technical knowledge and encourage reflection thereon, as there is a risk that the technical nature of the discipline can sacrifice the student's development by consuming the student's attention (Gray \& Collison, 2002). SAICA supports the view that teaching and assessment should take place with reference to contextualized problems, similar in spirit to those that would be encountered in the business environment (SAICA, 2014). Dewey (1915) understood knowledge as developing and growing through "experiment" or discovery. He argued that by combining theory and practice we learn knowledge ("theory") in the course of focused practical experimentation.

Case studies are useful teaching and assessment tools that encourage the development of professional skills (Cheng, 2007), and by making the cases "real and complex" (Montaño, Cardoso \& Joyce, 2004:191), they can promote 
problem-based learning (Milne \& McConnell, 2001). Weil, Oyelere, Yeoh and Firer (2001) also feel that the main benefits of using case studies are exposure to real-world complexity and by teaching students that there is rarely only one correct solution to business problems.

These notions support the purpose of the original study by Van der Merwe (2013:1137) to "explore more creative ways of delivering accounting curricula that will have a greater impact on skills development". They also offer justification for the current study's aim to gain insight into the effectiveness of case studies in promoting deeper levels of learning.

\section{RESEARCH METHODOLOGY}

A case study borrowed from Van der Merwe (2013) was administered at a different university to a larger population which consisted of students from more or less the same background as in the original study, namely from previously disadvantaged backgrounds. Some changes were made as to how the assignment was administered, and the same survey questionnaire consisting of 25 questions on a Likert-type scale was completed by 132 participants (56 in the original study). The results of the survey were then compared descriptively and statistically with the results of the original study.

The current study aimed to contribute to accounting education literature in three ways: 1) to corroborate or contradict the findings of the original study, 2) to explore how changes made to the way in which the assignment was administered may have influenced students' perceived development, and 3) to gain insight into the success of case studies in addressing the lack of professional skills and attributes in accounting curricula.

To answer research questions 1 and 2 the results of the two studies were analysed descriptively by comparison of means and mean rankings. Twenty-five null hypotheses (H0) were set in table 2 to test whether the distributions of each of the 25 items across the two institutions (University A and University B) ${ }^{1}$ were significantly different.

Table 2. Null hypotheses (H0) of the current study

\begin{tabular}{|c|c|}
\hline H0-1: & $\begin{array}{l}\text { The distributions of "My interest in chartered accountancy has been enhanced by the assignment" are the same for } \\
\text { both institutions. }\end{array}$ \\
\hline H0-2: & $\begin{array}{l}\text { The distributions of "Participating in the assignment enhanced my technical competencies" are the same for both } \\
\text { institutions. }\end{array}$ \\
\hline H0-3: & $\begin{array}{l}\text { The distributions of "Participating in the assignment broadened my view of the role of an accountant" are the same } \\
\text { for both institutions. }\end{array}$ \\
\hline H0-4: & The distributions of "The assignment tested my ability to think for myself" are the same for both institutions. \\
\hline H0-5: & $\begin{array}{l}\text { The distributions of "Participating in the assignment developed/enhanced my soft skills in general" are the same } \\
\text { for both institutions. }\end{array}$ \\
\hline H0-6: & $\begin{array}{l}\text { The distributions of "Participating in the assignment developed/enhanced my computer skills" are the same for } \\
\text { both institutions. }\end{array}$ \\
\hline H0-7: & $\begin{array}{l}\text { The distributions of "Participating in the assignment developed/enhanced my presentation skills" are the same for } \\
\text { both institutions. }\end{array}$ \\
\hline H0-8: & $\begin{array}{l}\text { The distributions of "Participating in the assignment developed/enhanced my communication skills" are the same } \\
\text { for both institutions. }\end{array}$ \\
\hline H0-9: & $\begin{array}{l}\text { The distributions of "Participating in the assignment developed/enhanced my teamwork skills" are the same for } \\
\text { both institutions. }\end{array}$ \\
\hline H0-10: & $\begin{array}{l}\text { The distributions of "Participating in the assignment developed/enhanced my report writing skills" are the same for } \\
\text { both institutions. }\end{array}$ \\
\hline H0-11: & $\begin{array}{l}\text { The distributions of "Participating in the assignment developed/enhanced my language skills" are the same for both } \\
\text { institutions. }\end{array}$ \\
\hline H0-12: & $\begin{array}{l}\text { The distributions of "Participating in the assignment developed/enhanced my research skills" are the same for both } \\
\text { institutions. }\end{array}$ \\
\hline
\end{tabular}

Reject the null hypothesis at the $p<.05$ level

(Table 2 continued on next page)

${ }^{1}$ For the purpose of this paper the institution where the original study was conducted and the institution where the follow-up study was conducted will be referred to as "University A" and "University B" respectively. 
(Table 2 continued)

\begin{tabular}{l|l}
\hline H0-13: & $\begin{array}{l}\text { The distributions of "Participating in the assignment developed/enhanced my time management skills" are the same } \\
\text { for both institutions. }\end{array}$ \\
\hline H0-14: & $\begin{array}{l}\text { The distributions of "Participating in the assignment developed/enhanced my stress management skills" are the } \\
\text { same for both institutions. }\end{array}$ \\
\hline H0-15: & $\begin{array}{l}\text { The distributions of "Participating in the assignment broadened my understanding of real-life practice" are the } \\
\text { same for both institutions. }\end{array}$ \\
\hline H0-16: & The distributions of "The assignment was an effective learning experience" are the same for both institutions. \\
\hline H0-17: & $\begin{array}{l}\text { The distributions of "What I have learned during the assignment will stay with me in the long run" are the same for } \\
\text { both institutions. }\end{array}$ \\
\hline H0-18: & $\begin{array}{l}\text { The distributions of "The assignment increased my insight into the relationship between theory and practice" are } \\
\text { the same for both institutions. }\end{array}$ \\
\hline H0-19: & $\begin{array}{l}\text { The distributions of "I am now more motivated to become a qualified accountant because of this assignment" are } \\
\text { the same for both institutions. }\end{array}$ \\
\hline H0-20: & The distributions of "I prefer such assignments instead of lectures" are the same for both institutions. \\
\hline H0-21: & The distributions of "I enjoyed the social aspects of the assignment" are the same for both institutions. \\
\hline H0-22: & The distributions of "I took the assignment seriously" are the same for both institutions. \\
\hline H0-23: & The distributions of "I was motivated by the assignment" are the same for both institutions. \\
\hline H0-24: & $\begin{array}{l}\text { The distributions of "The assignment demanded insight/application from me and not only knowledge replication" } \\
\text { are the same for both institutions. }\end{array}$ \\
\hline H0-25: & The distributions of "The assignment increased my knowledge" are the same for both institutions. \\
\hline Reject the null hypothesis at the $p<.05$ level
\end{tabular}

To answer research question 3 the assessment schedules that were completed by the evaluators (at University B only) were analysed descriptively by mean rankings and statistically using Friedman's Two-Way analysis of variance (ANOVA) by ranks. For the latter test, the seven assessment criteria were grouped into "soft skills" and "professional attributes" (the latter representing characteristics of life-long learning) to test whether students scored the same in both categories.

\section{THE CASE STUDY ASSIGNMENT}

The case study was borrowed from Van der Merwe (2013) and administered at a different South African university as part of the third-year CA degree course. The assignment aimed to simulate a real-life scenario where the students played the professional consultants and the instructor played the client. The company in the scenario was fictional, but was set in the real-world smartphone industry. The assignment was distributed to participants in the form of an email from the client with specific requirements included. The students had to work in groups of five and were given two weeks to prepare before presenting their solutions orally to the instructors. Some deliberate changes were made to the way in which the assignment was administered, compared to the original study, in order to investigate the impact this could have on the students' perceived development of professional skills and attributes.

The ways in which the administering of the assignment at University B differed from University A are as follows:

1. The assignment was compulsory for all third-year accounting students and formed part of their CAM. In the original study students volunteered to participate in the assignment in order to improve their CAM;

2. Two days prior to receiving the case study, students participated in a training course on presentation and case analysis skills presented by training specialists from a local professional accounting and auditing firm. In the original study students had not receive this training before the assignment;

3. The team members were assigned to groups by the instructor based on their grades in the prerequisite module for the course in which this assignment was graded, as opposed to self-selected groups at University A; and

4. Students were not allowed to consult with lecturers before presenting their results. In the original study the instructor gave homework assistance via an online blog where students could pose questions as part of the real-life "consultant-client" role play. 


\section{RESULTS: STUDENT FEEDBACK}

The feedback obtained after completing the assignment was in the form of a five-point Likert-scale questionnaire ( 1 = "strongly disagree"; 5 = "strongly agree") (Van der Merwe, 2013). Self-reported levels of knowledge or skills are widely used in accounting education research (e.g., DeBoskey, 2009; Ballantine \& McCourt Larres, 2009). The following two items were added (resulting in a total of 27 questions): 1) a question to assess the students' perceived development or enhancement of their ethical awareness, since Van der Merwe (2013) reported that his students either did not pick up on the ethical/governance/fraud risks or they might have felt uncomfortable asking these questions of their lecturer; and 2) a question to assess the students' perceived development of interpersonal skills due to being assigned to a group as opposed to choosing team members.

By comparing the means of the items from both studies in figure 1 the results of this study largely mirror, and thus corroborate, the results of the original study. This suggests that the changes made to the way in which the assignment was administered at the two institutions did not have a significant effect on the students' learning experience and perceived development of professional skills after participating in the case study.

Figure 1. Means of the items of University A and University B

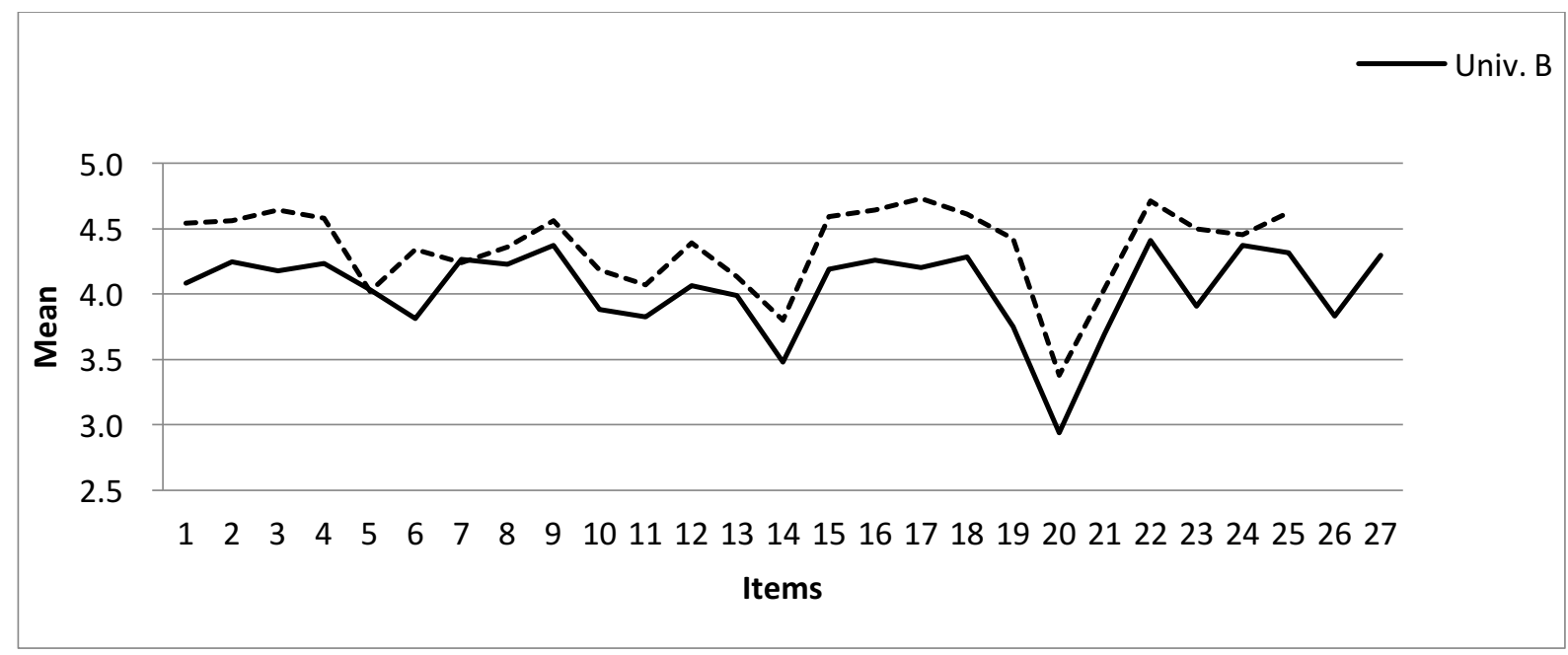

From figure 1 it is evident that students in the original study generally responded more positively than the students in the follow-up study. The line graph tracking the mean responses for University A are higher than that of University B except for two items, namely the development and enhancement of "soft skills in general" (item 5) and "presentation skills" (item 7).

Even though there may be various reasons for the more positive responses in the original study, it must be mentioned that one notable difference in the samples could have caused a negative bias to University B's responses relative to the responses of University A: The assignment was compulsory for all third-year accounting students at University B, whereas the participants at University A voluntarily signed up for the assignment in order to improve their CAM. This means that the results of University B include the responses of students who might not have been interested in the assignment and who would have lacked the proper motivation to volunteer for the assignment at University A. This could have influenced the means and response distributions; thus, the relative mean rankings remain important when comparing the perceptions of the students' experiences between the two studies. As can be seen from figure 1, the two studies show a remarkably similar trend in that the two line graphs follow similar peaks and troughs. 


\section{Descriptive and Statistical Analysis}

The results of the survey questionnaires were analysed descriptively by ranking the items for both samples by their relative means (see appendix A), as well as statistically by performing the Mann-Whitney u-test for non-parametric independent samples using the statistics software package SPSS Version 22.

\section{Compulsory Participation for Graded Assessment}

In addition to nearly all of the items being scored more positively by University A where the assignment was voluntary, the results show a statistically significant difference in the distributions of responses to the item on "motivated by the assignment" $(p=.000)$ and "took the assignment seriously" $(p=.027)$, with University A showing more positive responses for both items. The means of the latter item ranked $1^{\text {st }}$ and $2^{\text {nd }}$ (relative to the other items) at University B and University A respectively. This supports the well-documented observation that students are assessment driven (Biggs, 1996).

\section{Inclusion of a Course On Presentation Skills and Case Analysis}

Before the assignment was distributed to the students of University B, they had to attend a two-day course presented by training specialists from a local professional accounting and auditing firm. The focus of the course was presentation skills and case analysis.

Figure 1 shows that the only items where University B participants responded with means higher than University A are the items of "soft skills in general" and "presentation skills" which were the focus areas of the short course. The relative rankings of the means of these items improved from 23 to 17, and 18 to 7, respectively. Even though the distributions of the responses did not differ significantly ( $p=.680$ and $p=.497$ respectively), the change in mean rankings is an indication that inclusion of a short course focusing on certain items before the assignment was likely to have increased students' perceived development of these skills by participating in the assignment.

\section{Instructor-Imposed Groups Versus Self-Selection}

Motivated by Van der Laan Smith and Spindle (2007) who found that self-selected groups may augment the effectiveness of individual and cooperative learning, Van der Merwe (2013) opted for self-selected groups in the original study. Similarly, Chapman, Meuter, Toy and Wright (2006) support self-selection as they found improved ratings relating to teamwork, networking, group attitude and outcome measures. They did, however, report lower group efficiency and slightly higher degrees of conflict. A distinction needs to be drawn between perceived effectiveness of teamwork (most closely related to the item of "perceived effective cooperative learning") and perceived development of teamwork skills.

In the follow-up study, instructor-imposed teams were chosen in order to assess whether there would be a change in the perceived development of teamwork skills, as well as the perceived effectiveness of the learning experience. The relative ranking of the means of the item "development of teamwork skills" ranked $3^{\text {rd }}$ at University B and $9^{\text {th }}$ at University A. Even though the differences in the distributions of the responses for this item was insignificant $(p=$ .095), they still suggest that instructor-imposed heterogeneity was perceived by students to better develop teamwork skills.

On the other hand, the ranking of the means of the item "effective learning experience", cited as the reason for selfselection in the original study, resulted in the mean ranking $3^{\text {rd }}$ at University A and 8 th in University B with a significant difference in the distribution of the responses $(p=.001)$. This supports the suggestion that self-selection increases the effectiveness of cooperative learning and, importantly, the perceived effectiveness of individual learning.

\section{Homework Assistance}

In the original study homework assistance was offered in the form of an online blog where students could ask questions when they got stuck (Van der Merwe, 2013). Since Lindquist and Olsen (2007) found no difference in knowledge 
gains with or without homework assistance, it was decided in the follow-up study to withhold assistance in order to develop the items of "understanding of real-life practice" and "ability to think for myself". Also, assistance is not always available in the workplace, and qualified professional accountants are required to be able to think for themselves.

Both items, however, ranked higher in the original study where homework assistance was available, with the differences in the distributions being statistically significant ( $p=.004$ and $p=.008$ respectively). Lindquist and Olsen (2007) reported that higher student satisfaction and lower frustration with the assignments were experienced where homework assistance was offered. These findings are supported by statistically significant differences in the distributions of the items of "motivated by the assignment" $(p=.000)$ and "effective learning experience" $(p=.001)$, with University A showing more positive responses. There may, however, be other reasons for these significant differences such as compulsory versus voluntary participation, and self-selection versus instructor-imposed groups, as was mentioned earlier.

\section{RESULTS: ASSESSMENT SCHEDULES}

There were 30 groups consisting of five students each in the University B study. Four groups had an additional member and the last group had seven students due to late registrations for the course in which the assignment was run. Evaluation of the presentations was done by pairs of academic staff from the Department of Accounting, all of whom are qualified CAs (SA). The teams were each given 25 minutes to present their case, and five minutes were allowed for the evaluators to ask questions. The questions were meant to test the participants' ability to think on their feet and to ascertain whether they really understand what they were presenting. Each evaluator had to complete an assessment schedule that was prepared by the authors. The schedule contained seven categories for which a score from 0 to 10 had to be given, 10 representing the maximum score. The average of all seven categories was the grade that counted towards each team member's CAM. Students were aware that the score they received would count towards their mark and that they were responsible for motivating their team members to contribute towards a good presentation.

The seven criteria of the assessment schedule were grouped into two main categories, namely 1. "soft skills" (e.g., communication; use of technology; structure of presentation; and teamwork) and 2. "professional attributes" (e.g., ability to assimilate new technical knowledge; depth and breadth of understanding, and linking theory with practice; and relevance of findings).

Table 3 provides descriptive statistics on the results of the assessment schedules. The table has been sorted in descending order of mean scores. Some evaluators discussed the results and filled in one form with a unanimous result, thus the reason for there being only 55 assessment schedules.

Table 3. Descriptive statistics on results of the assessment schedules

\begin{tabular}{|c|c|c|c|}
\hline & $\mathbf{N}$ & Mean & $\begin{array}{l}\text { Std. } \\
\text { Dev. }\end{array}$ \\
\hline Effective teamwork (as evidenced by cohesiveness of presentation and question session) $[\mathrm{C} 7]^{2}$ & 55 & 6.72 & 0.947 \\
\hline Presentation and oral communication skills [C2] & 55 & 6.64 & 1.025 \\
\hline Effective use of information technology [C1] & 55 & 6.56 & 0.977 \\
\hline Structure, sequencing and time management of presentation [C6] & 55 & 6.53 & 1.073 \\
\hline Relevance of discussions, calculations, findings and conclusions [C5] & 55 & 6.44 & 0.923 \\
\hline Depth and breadth of understanding and linking theory with practice [C4] & 55 & 6.40 & 1.069 \\
\hline Ability to assimilate and apply predominantly new technical knowledge [C3] & 55 & 6.23 & 0.937 \\
\hline
\end{tabular}

Table 3 shows that the four assessment criteria grouped under the category of "soft skills" were scored the highest. This may have been, in part, as a result of the course on presentation skills and case study analysis in which the students participated before starting the assignment, but it could also be that this sort of group work assignment is simply better suited to developing soft skills compared to technical skills, deeper understanding and insight. It is interesting to note that the teams scored the highest on "effective teamwork", this despite instructor-imposed teams.

\footnotetext{
${ }^{2}$ The numbers [Cn] relate to the original numbering of the criteria as per the assessment schedules completed by the evaluators.
} 
This is in contrast to findings from Van der Laan Smith and Spindle (2007) who established that self-selected groups could increase the effectiveness of cooperative learning.

Table 3 further shows that the three assessment criteria that formed part of the category "professional attributes" scored the lowest. This supports the general perception of academics, based on anecdotal evidence from their interactions with students (Cairney, 2010) and the predictions made in the literature review, that accountancy students generally find it difficult to apply professional judgement. The lower scores in the category "professional attributes" further suggests that accountancy students generally fall within the lower levels of knowing of Baxter-Magolda's Epistemological Reflection Model (ERM) as reported by Lucas and Tan (2006b).

To test whether the distributions of the scores in each category differed significantly, a Friedman's test, with pairwise comparison, was performed on the weighted average of the two categories and the sum of the two categories. Table 4 shows that the distributions of the weighted average scores for the four assessment criteria under category "soft skills" differed significantly $(p=.027)$ from the distributions of the weighted average scores for the three assessment criteria under category "professional attributes".

Table 4. Related samples Friedman's two-way analysis of variance by ranks

\begin{tabular}{c|l|c|c}
\hline \multicolumn{1}{|c}{ Null Hypothesis } & Sig. & \multicolumn{1}{c}{ Decision } \\
\hline $\mathbf{1}$ & $\begin{array}{l}\text { The distributions of weighted average }(\mathrm{C} 1, \mathrm{C} 2, \mathrm{C} 6, \mathrm{C} 7) \text { and weighted } \\
\text { average }(\mathrm{C} 3, \mathrm{C} 4, \mathrm{C} 5) \text { are the same. }\end{array}$ & .027 & Reject the null hypothesis \\
\hline $\mathbf{2}$ & $\begin{array}{l}\text { The distributions of sum }(\mathrm{C} 1, \mathrm{C} 2, \mathrm{C} 6, \mathrm{C} 7) \text { and sum }(\mathrm{C} 3, \mathrm{C} 4, \mathrm{C} 5) \text { are the } \\
\text { same. }\end{array}$ & .000 & Reject the null hypothesis \\
\hline Asymptotic significances are displayed. Reject the null hypothesis at the $p<.05$ level
\end{tabular}

Table 4 also shows that the distributions of the sums of the scores for the four assessment criteria under category "soft skills" differed significantly $(p=.000)$ from the distributions of the sums of the scores for the three assessment criteria under category "professional attributes".

It can, therefore, be concluded that, even though the students perceived the business simulation and case study assignment to be effective in developing specific professional skills and attributes as required by the profession, the findings of an analysis of the assessment schedules show that students generally fared better in the "soft skills" than the "professional attributes".

\section{CONCLUSION}

This paper reported on a study following an original study (Van der Merwe, 2013) which explored the experiences of a group of previously disadvantaged South African CA students who participated in an integrated case study assignment. The purpose of the paper was to corroborate the findings of the original study, investigate the effect of changes in the way the assignment was administered and gain some insight into the actual improvement of students' professional skills and attributes.

The responses from participants in the follow-up study mirrored the generally positive responses from the original study; however, all the means except for two items were slightly lower in the current study. The items of "soft skills in general" and "presentation skills" scored higher in the follow-up study, which may have been due to the students" attending a short course focusing on these skills before the study. A possible explanation for the overall lower scores for all the other items may be the fact that participation in the assignment was voluntary in the original study, thus excluding the responses of the disinterested students who were required to partake in the follow-up study.

The results of this study and comparison with the original study also support Van der Laan Smith and Spindle's (2007) and Chapman et al.'s (2006) findings that effective learning is enhanced by self-selection of groups. There was, however, an indication that instructor-imposed heterogeneous groups might be more effective in developing teamwork skills than self-selected groups. Further research is required to establish whether this is the case, since the issue is not sufficiently addressed in the literature. The objective of the assignment (pervasive skills versus knowledge/other learning) should, however, be taken into account before deciding on the group selection method, since instructorimposed composition appears less conducive to more effective cooperative learning. 
Even though it was not possible to prove the effect of withholding homework assistance on students' perceptions in the follow-up study, the distributions of the responses to the items which would be expected to be affected all differed significantly from the original study. Since they represent students' perceptions and may have been influenced by other factors, more research needs to be conducted to investigate the merits of providing assistance.

The paper contributed to the literature with regard to actual learning by analyzing the assessment schedules that were completed by the evaluators. The findings suggest that the assignment had a greater impact on the development of the more general "soft skills" than the deeper levels of learning Baxter-Magolda (2001) refers to. This offers support for the perception that students are seemingly not applying their knowledge sufficiently and thinking through problems in a contextual way as required by both accounting academics and the profession, and that the challenge accounting educators face is real. It also highlights, once again, the importance of research attempting to find solutions to the crucial issue of skills development in accounting education.

\section{REFERENCES}

Abayadeera, N., \& Watty, K. (2014). The expectation-performance gap in generic skills in accounting graduates: Evidence from Sri Lanka. Asian Review of Accounting, 22(1), 56-72.

Ahmad, N.N.N. (2011). Teaching the case method in an advanced management accounting course in a passive learning environment. International Journal of Accounting and Finance, 3(1), 33-48.

Apostolou, B., Hassell, J.M., Rebele, J.E., \& Watson, S.F. (2010). Accounting education literature review (2006-2009). Journal of Accounting Education, 28(3-4), 145-197.

Ashbaugh, H., \& Johnstone, K.M. (2000). Developing students' technical knowledge and professional skills: a sequence of short cases in intermediate financial accounting. Issues in Accounting Education, 15(1), 67-88.

Avramenko, A. (2012). Enhancing students' employability through business simulation. Education \& Training, 54(5), 355-367.

Ballantine, J.A., \& McCourt Larres, P. (2004). A critical analysis of students' perceptions of the usefulness of the case study method in an advanced management accounting module: the impact of relevant work experience. Accounting Education, 13(2), 171-189.

Ballantine, J.A., \& McCourt Larres, P. (2009). Accounting undergraduates' perceptions of cooperative learning as a model for enhancing their interpersonal and communication skills to interface successfully with professional accountancy education and training. Accounting Education: An International Journal, 18(4/5), 387-402.

Barac, K. (2009). South African training officers' perceptions of the knowledge and skills requirements of entry-level trainee accountants. Meditari Accountancy Research, 17(2), 19-46.

Baxter-Magolda, M.B. (2001). Making their own way: narratives for transforming higher education to promote selfdevelopment. Sterling, VA: Stylus.

Biggs, J. (1996). Assessing learning quality: reconciling institutional, staff and educational demands. Assessment \& Evaluation in Higher Education, 21(1), 5-15.

Byrne, M., \& Flood, B. (2003) Exploring the conceptions of learning of accounting students. Accounting Education, 13(Supplement 1), 25-37.

Cairney, C.A. (2010). An investigation into the ways of knowing of South African post graduate students pursuing a professional accounting qualification. MSc dissertation in Financial Management. Bristol: University of the West of England.

Chapman, K.J., Meuter, M., Toy, C., \& Wright, L. (2006). Can’t we pick our own groups? The influence of group selection method on group dynamics and outcomes. Journal of Management Education, 30(4), 557-569.

Cheng, K. (2007). The curriculum design in universities from the perspective of providers in accounting education. Education, 127(4), 581-590.

Council on Higher Education. (2004). Criteria for programme accreditation. Pretoria: CHE.

De Lange, P., Jackling, B., \& Gut, A. (2006). Accounting graduates' perceptions of skills emphasis in undergraduate courses: an investigation from two Victorian universities. Accounting \& Finance, 46, 365-386.

DeBoskey, D.G. (2009). Enhancing teaching effectiveness of financial accounting to Chinese executives - a generalized approach with case study and assessments. Issues in Accounting Education, 24(4), 511-529.

Dewey, J. (1915). The school and society (revised edition, 10). Chicago: University of Chicago Press.

Duit, R., \& Treagust, D.F. (1998). Learning in science: from behaviourism towards social constructivism and beyond. In B.J. Fraser, \& K.G. Tobin (Eds), International handbook of science education (pp. 3-25). Great Britain: Kluwer Academic Publishers.

Finch, D.J., Hamilton, L.K., Baldwin, R., \& Zehner, M. (2013). An exploratory study of factors affecting undergraduate employability. Education + Training, 55(7), 681-704.

Fortin, A., \& Legault, M. (2010). Development of generic competencies: impact of a mixed teaching approach on students' perceptions. Accounting Education: An International Journal, 19(1-2), 93-122.

Fouché, J.P., \& Visser, S.S. (2008). An evaluation of the integration of a board game in introductory accounting. South African 
Journal of Higher Education, 22(3), 588-601.

Gray, R., \& Collison, D. (2002). Can't see the wood for the trees. Can't see the trees for the numbers? Accounting education, sustainability and the public interest. Critical Perspectives on Accounting, 13, 797-836.

Hall, M., Ramsay, A., \& Raven, J. (2004). Changing the learning environment to promote deep learning approaches in first-year accounting students. Accounting Education, 13(4), 489-505.

Hassall, T., \& Milne, M.J. (2004). Using case studies in accounting education. Accounting Education, 13(2), 135-138.

Healy, M., \& McCutcheon, M. (2010). Teaching with case studies: an empirical investigation of accounting lecturers' experiences. Accounting Education: An International Journal, 19(6), 555-567.

Howieson, B., Hancock, P., Segal, N., Kavanagh, M., Tempone, I., \& Kent, J. (2014). Who should teach what? Australian perceptions of the roles of universities and practice in the education of professional accountants. Journal of Accounting Education, 32, 259-275.

IFAC (International Federation of Accountants). (2003a). Introduction to International Education Standards. Retrieved October 6, 2014, from https://www.ifac.org/sites/default/files/ publications/files /introduction-to-internation.pdf

IFAC (International Federation of Accountants). (2003b). International Education Standards 2. Retrieved October 6, 2014, from https://www.ifac.org/sites/default/files/publications/ files/ies-2-content-of-professi.pdf

Kavanagh, M.H., \& Drennan, L. (2008). What skills and attributes does an accounting graduate need? Evidence from student perceptions and employer expectations. Accounting \& Finance, 48(2), 279-300.

Koenecke, W. (2012). Progressivism, essentialism, perennialism, \& postmodernism. Murray State University. Retrieved May 19, 2012, from http://coekate.murraystate.edu/professor/koenecke/pages/progressivism-essentialism-perennialismpostmodern/

Korn, M. (2014, October 21). Bosses seek “critical thinking”, but what is that? Wall Street Journal. Retrieved March 3, 2016, from http://www.wsj.com/articles/bosses-seek-critical-thinking-but-what-is-that-1413923730

Leung, D., \& Kember, D. (2003). The relationship between approaches to learning and reflection upon practice. Educational Psychology, 23(1), 61-71.

Lindquist, T.M., \& Olsen, L.M. (2007). How much help, is too much help? An experimental investigation of the use of check figures and completed solutions in teaching intermediate accounting. Journal of Accounting Education, 25(3), 103-117.

Link, S. (2008). Essentialism \& perennialism: research starters education. Ebsco Publishing. Retrieved May 19, 2012, from Available at: http://www.dswleads.com/Ebsco/Essentialism\%20\&\%20Perennialism.pdf

Low, M., Samkin, G., \& Liu, C. (2013). Accounting education and the provision of soft skills: implications of the recent NZICA CA academic requirement changes. e-Journal of Business Education \& Scholarship of Teaching, 7(1), 1-33.

Lucas, U., \& Tan, P.L. (2006a). Assessing levels of reflective thinking: The evaluation of an instrument for use within accounting and business education. Paper presented to the 1st Pedagogic Research in Higher Education Conference, Liverpool Hope University, Liverpool, 2-3 May.

Lucas, U., \& Tan, P.L. (2006b). Developing a reflective capacity: the role of personal epistemologies within undergraduate education. 14th Improving Student Learning Symposium, University of Bath, 4-6 September.

Martinov-Bennie, N., \& Mladenovic, R. (2015). Investigation of the impact of an ethical framework and an integrated ethics education on accounting students' ethical sensitivity and judgement. Journal of Business Ethics, 127, 189-203.

Mezirow, J. (1998). On critical reflection. Adult Education Quarterly, 48(3), 185-198.

Milne, M.J., \& McConnell, P.J. (2001). Problem-based learning: a pedagogy for using case material in accounting education. Accounting Education, 10(1), 61-82.

Montaño, J.L.A., Cardoso, S.M.J., \& Joyce, J. (2004). Skills development, motivation and learning in financial statement analysis: an evaluation of alternative types of case studies. Accounting Education, 13(2), 191-212.

Riley, R.A. Jr., Cadotte, E.R., Bonney, L., \& MacGuire, C. (2013). Using a business simulation to enhance accounting education. Issues in Accounting Education, 28(4), 801-822.

Robles, M.M. (2012). Executive perceptions of the top 10 soft skills needed in today's workplace. Business Communication Quarterly, 75(4), 453-465.

Schunk, D.H. (2011). Learning theories: an educational perspective (6th ed.). Boston, MA: Pearson Education.

South African Institute of Chartered Accountants (SAICA). (2014). Competency framework detailed guidance for the academic programme: Competencies of a CA(SA) at the point of the Initial Test of Competence (ITC) (assessment of core technical knowledge). Johannesburg: SAICA.

South African Institute of Chartered Accountants (SAICA). (2003-2014). SAICA examiners comments for Part I of the Qualifying Examination (Initial Test of Competence). Retrieved October 6, 2014, from https://www.saica.co.za/LearnersStudents/Examinations/ExamInformation/PastExamPapers/ PartIQualifyingExamination/tabid/1168/language/en-ZA/Default.aspx

Steenkamp, L.P., \& Rudman, R.J. (2007). South African students' perceptions of the usefulness of an audit simulation. Meditari Accountancy Research, 15(2), 23-41.

Tanaka, S., \& Sithole, M. (2015). Quality in accounting graduates: employer expectations of the graduate skills in the Bachelor of Accounting degree. European Scientific Journal, 11(22), 165-180.

Towler, M., Lean, J., \& Moizer, J.D. (2009). An exploration of student perception of a business simulation game. International Journal of Management Education, 7(2), 69-79. 
Van der Laan Smith, J., \& Spindle, R.M. (2007). The impact of group formation in a cooperative learning environment. Journal of Accounting Education, 25(4), 153-167.

Van der Merwe, N. (2013). An evaluation of an integrated case study and business simulation to develop professional skills in South African accountancy students. International Business \& Economics Research Journal, 12(10), 1137-1156.

Weil, S., Oyelere, P., \& Rainsbury, E. (2004). The usefulness of case studies in developing core competencies in a professional accounting programme: a New Zealand study. Accounting Education, 13(2), 139-169.

Weil, S., Oyelere, P., Yeoh, J., \& Firer, C. (2001). A study of students' perceptions of the usefulness of case studies for the development of finance and accounting-related skills and knowledge. Accounting Education, 10(2), 123-146.

Wynn-Williams, K., Whiting, R.H., \& Adler, R.W. (2008). The influence of business case studies on learning styles: an empirical investigation. Accounting Education, 17(2), 113-128.

Xu, Y., \& Yang, Y. (2010). Student learning in business simulation: an empirical investigation. Journal of Education for Business, 85, 223-228.

Yu, S.C., Churyk, N.T., \& Chang, A.C. (2013). Are students ready for their future accounting careers? Insights from observed perception gaps among employers, interns, and alumni. Global Perspectives on Accounting Education, 10, 1-15. 
APPENDIX A: Mean rankings of student feedback in both studies

\begin{tabular}{|c|c|c|c|c|c|c|}
\hline & \multicolumn{3}{|c|}{ University B } & \multicolumn{3}{|c|}{ University A } \\
\hline & Rank & Mean & Std. Dev. & Rank & Mean & Std. Dev. \\
\hline 1. I took the assignment seriously & 1 & 4.41 & .859 & 2 & 4.71 & .494 \\
\hline $\begin{array}{l}\text { 2. The assignment demanded insight/application from } \\
\text { me and not only knowledge replication }\end{array}$ & 2 & 4.37 & .823 & 13 & 4.45 & .537 \\
\hline $\begin{array}{l}\text { 3. Participating in the assignment developed/enhanced } \\
\text { my teamwork skills }\end{array}$ & 3 & 4.37 & .786 & 9 & 4.56 & 660 \\
\hline 4. The assignment increased my knowledge & 4 & 4.32 & .869 & 5 & 4.62 & .558 \\
\hline $\begin{array}{l}\text { 5. Being assigned to a group for the assignment } \\
\text { developed/enhanced my interpersonal skills }\end{array}$ & 5 & 4.30 & .880 & $\mathrm{n} / \mathrm{a}$ & - & - \\
\hline $\begin{array}{l}\text { 6. The assignment increased my insight into the } \\
\text { relationship between theory and practice }\end{array}$ & 6 & 4.28 & .896 & 6 & 4.61 & .493 \\
\hline $\begin{array}{l}\text { 7. Participating in the assignment developed/enhanced } \\
\text { my presentation skills }\end{array}$ & 7 & 4.27 & .863 & 18 & 4.24 & .744 \\
\hline 8. The assignment was an effective learning experience & 8 & 4.26 & .806 & 3 & 4.64 & .616 \\
\hline $\begin{array}{l}\text { 9. Participating in the assignment enhanced my } \\
\text { technical competencies }\end{array}$ & 9 & 4.24 & .802 & 10 & 4.56 & .601 \\
\hline 10. The assignment tested my ability to think for myself & 10 & 4.23 & .867 & 8 & 4.58 & .629 \\
\hline $\begin{array}{l}\text { 11. Participating in the assignment developed/enhanced } \\
\text { my communication skills }\end{array}$ & 11 & 4.23 & .834 & 16 & 4.36 & .672 \\
\hline $\begin{array}{l}\text { 12. What I have learned during the assignment will stay } \\
\text { with me in the long run }\end{array}$ & 12 & 4.20 & .918 & 1 & 4.73 & .486 \\
\hline $\begin{array}{l}\text { 13. Participating in the assignment broadened my } \\
\text { understanding of real-life practice }\end{array}$ & 13 & 4.19 & .903 & 7 & 4.59 & .596 \\
\hline $\begin{array}{l}\text { 14. Participating in the assignment broadened my view } \\
\text { of the role of an accountant }\end{array}$ & 14 & 4.18 & .969 & 4 & 4.64 & .554 \\
\hline $\begin{array}{l}\text { 15. My interest in chartered accountancy has been } \\
\text { enhanced by the assignment }\end{array}$ & 15 & 4.08 & .829 & 11 & 4.54 & .687 \\
\hline $\begin{array}{l}\text { 16. Participating in the assignment developed/enhanced } \\
\text { my research skills }\end{array}$ & 16 & 4.06 & .955 & 15 & 4.39 & .652 \\
\hline $\begin{array}{l}\text { 17. Participating in the assignment developed/enhanced } \\
\text { my soft skills in general }\end{array}$ & 17 & 4.03 & .862 & 23 & 4.02 & .774 \\
\hline $\begin{array}{l}\text { 18. Participating in the assignment developed/enhanced } \\
\text { my time management skills }\end{array}$ & 18 & 3.98 & .933 & 20 & 4.13 & .810 \\
\hline 19. I was motivated by the assignment & 19 & 3.91 & .996 & 12 & 4.50 & .505 \\
\hline $\begin{array}{l}\text { 20. Participating in the assignment developed/enhanced } \\
\text { my report writing skills }\end{array}$ & 20 & 3.88 & .933 & 19 & 4.18 & .748 \\
\hline $\begin{array}{l}\text { 21. Participating in the assignment developed/enhanced } \\
\text { my ethical awareness }\end{array}$ & 21 & 3.83 & .974 & $\mathrm{n} / \mathrm{a}$ & - & - \\
\hline $\begin{array}{l}\text { 22. Participating in the assignment developed/enhanced } \\
\text { my language skills }\end{array}$ & 22 & 3.82 & .937 & 21 & 4.07 & .920 \\
\hline $\begin{array}{l}\text { 23. Participating in the assignment developed/enhanced } \\
\text { my computer skills }\end{array}$ & 23 & 3.81 & 1.085 & 17 & 4.34 & .721 \\
\hline $\begin{array}{l}\text { 24. I am now more motivated to become a qualified } \\
\text { accountant because of this assignment }\end{array}$ & 24 & 3.75 & 1.152 & 14 & 4.42 & .762 \\
\hline 25. I enjoyed the social aspects of the assignment & 25 & 3.69 & 1.210 & 22 & 4.04 & .953 \\
\hline $\begin{array}{l}\text { 26. Participating in the assignment developed/enhanced } \\
\text { my stress management skills }\end{array}$ & 26 & 3.48 & 1.138 & 24 & 3.80 & .999 \\
\hline 27. I prefer such courses/assignments instead of lectures & 27 & 2.94 & 1.317 & 25 & 3.38 & 1.315 \\
\hline
\end{tabular}

